Vannoni, M; (2013) The determinants of direct corporate lobbying in the EU: A multi-dimensional proxy of corporate lobbying. Interest Groups \& Advocacy, 2 (1) pp. 71-90. 10.1057/iga.2012.16. Downloaded from UCL Discovery: http://discovery.ucl.ac.uk/1460771

\title{
ARTICLE
}

\section{The Determinants of Direct Corporate Lobbying in the EU: a Multi- dimensional Proxy of Corporate Lobbying}

\author{
Vannoni, Matia \\ School of Arts and Social Sciences, University College London
}

\section{Executive summary}

This article argues for a more thorough analysis of the dynamics of corporate lobbying within the European Union (EU). While there is broad consensus among scholars on the emergence of a new type of European lobbying, studies have not sufficiently addressed the underlying economic rationale. Indeed, many authors emphasise the shift towards a system based on direct lobbying, however, these concentre only on systemic and non-economic causes. Direct lobbying dynamics are perceived mainly in two ways: either as a consequence of a conscious political strategy of the European institutions in response to the 'interest overload' (Coen, 2007) of the mid-1990s (e.g. Broscheid and Coen, 2003; Coen, 1998) or as a normal phase of the development of interest group populations (e.g. Berkhout and Lowery, 2010; Gray and Lowery, 1996). Advocating an economics based analytical approach to European corporate lobbying, this contribution to the debate provides one of the very first attempts to uncover the influence of economic factors on direct corporate lobbying by building on the seminal work proposed by Bernhagen and Mitchell (2009).

These authors, very familiar with the American tradition of corporate lobbying studies, were the first to apply a 'standard model of corporate political behaviour' to the European context by examining the various determinants of direct lobbying. This article goes further: it analyses the empirical database constructed by Bernhagen and Mitchell (2009), with a multi-dimensional proxy of corporate lobbying. Indeed, the main contribution of this study is in its analysis, namely the operationalisation of the dependent variable 'direct lobbying'. It proposes a multi-strategy/multivenue operationalisation of the dependent variable aiming to overcome the pitfalls which characterise dichotomous and uni-dimensional operational definitions, in order to answer the research question: 'What are the economic determinants of direct corporate lobbying in the EU?'

Such a multi-dimensional operationalisation of the dependent variable has required the unpacking of some of the elements taken for granted in the discussion on corporate lobbying. The discussion argues that the researcher needs to take into consideration the various direct lobbying strategies and their relative weights (i.e. the multi-strategy operationalisation ${ }^{1}$ ). For example accreditation to the EP is not equal to the establishment of a company representation office in Brussels. Furthermore, another possible level of action of a firm's strategy, namely the industry one, should also be considered (i.e. the multi-venue operationalisation ${ }^{2}$ ): direct lobbying should be analysed as a preference over other lobbying approaches rather than in absolute terms.

The findings show how such an expanded operationalisation casts light on the economic determinants of European corporate lobbying. First of all, the Olsonian argument finds empirical support: industry concentration determines lobbying strategies, indeed. Secondly, asset mobility/specificity influences a firm's preference to lobby directly vis-à-vis other venues. 
Keywords: European Union; Corporate lobbying; Olsonian argument; collective action problems; factor endowments trade theories; asset specificity.

\section{The Determinants of Direct Corporate Lobbying in the EU}

This section supplies a brief overview of the Olsonian tradition of lobbying studies and of the endogenous tariff literature. The former identifies in the degree of industry concentration a crucial element affecting corporate political strategy: concentrated production segments markets thus creating favourable environments where firms may overcome the typical problems connected to collective action. The latter emphasises the importance of production factors and their relative endowments. Indeed, depending on the endowment of production factors, trade induced adjustment costs are imposed upon factors (i.e. capital or labour) or industries. Accordingly, assuming (explicitly, e.g. Furusawa and Lai, 1999 or implicitly, e.g. Bhagwati, 1992) lobbying as a substitute for adjustment, coalitions form either along factoral lines or industry lines. In addition, other minor approaches considered relevant for the analysis are taken into consideration.

Four main hypotheses derive from the research question formulated above thus identifying four economic determinants of direct lobbying: industry concentration, firm size, asset specificity and foreign investments. These hypotheses will then be operationalised into explanatory variables ${ }^{3}$ to be tested against the dependent variable. Worthy of note is that also private rents are listed amongst the explanatory variables because, although they are not economic determinants in the proper sense, they are directly linked to direct lobbying Another type of hypotheses differentiated according to the nature of the variables they give rise to, namely control variables ${ }^{4}$, is inferred. These represent those factors associated with the activity of the firm regardless of the venue of lobbying: even though they are not directly linked to direct lobbying, they can skew the analysis if not taken under control.

Industry Concentration and Collective Action

Collective action problems, in the Olsonian conception, have been the dominant leitmotif of empirical research in the American tradition over the last three decades (Baumgartner and Leech, 1998; Lowery and Gray, 2004). Indeed, since the pioneering works of Esty and Caves (1983), Munger (1988) and others, measuring market structure via concentration ratios has become a standard analytical practice. Accordingly, concentration ratios have come predominantly to the fore as the main operational definition of market structure. Firms are incentivised to act collectively since their political weight augments. Conversely, where markets comprise large numbers of small firms producing in dispersed industries, heavy collective action problems lead the firm to act individually. The hypothesis inferred is as follows:

\section{H-e1: Ceteris paribus, firms acting in dispersed industries will be more likely to lobby directly}

Despite the theoretical appeal, the Olsonian argument has hitherto received little empirical support (Lowery and Gray, 2004; Hansen et al, 2005; Ozer and Lee, 2009). Hansen et al (2005) review several well known studies which attempt to establish a correlation between industry concentration and firm political activity. That none of them has found any form of relevant correlation speaks volumes. Moreover, this hypothesis has also been operationalised and tested in the European context by Bernhagen and Mitchell (2009) with limited results. Therefore the remainder of this paper will operationalise the dependent variable, namely direct lobbying, in a novel way. The objective is to investigate in a possibly more rewarding way whether the Olsonian argument finds support in the European lobbying context.

Previously a range of different analytical devices have been tried. This paper proposes a more sophisticated operationalisation of corporate lobbying. Hansen et al (2005) criticise the normal dichotomous conception of corporate lobbying. Close in spirit to the study of electoral politics, they argue in favour of the categorisation of political behaviours. In fact, just as electoral behaviour 
studies differentiate across a wide spectrum of types of participation, Hansen et al (2005) advocate an ordering of the different strategies employed by firms. As a result, they create an ordered categorisation of corporate participation to test the validity of the Olsonian argument in a more reliable manner. The same rationale will be applied below where the concept of participation is operationalised to fit the European context.

Ozer and Lee (2009) go further by giving theoretical foundation and empirical testability to the differentiation between direct and collective lobbying. This study embraces the concept of 'venue shopping'5 (Baumgartner and Jones, 1993) by criticising the counterpoised relation between individual and collective action that has characterised the empirical research in this field. The interaction between levels of participation assumes a central position in determining firms' political strategy and attention shifts to a theoretical framework determining firms' preference for one level of participation rather than another. In other words, individual action is conceptualised and operationalised in terms of preference, rather than in terms of a dichotomy vis-à-vis collective action. In this vein, the researcher can control the incentives for direct lobbying. The next section will apply this rationale to the analysis of European corporate lobbying.

Recent developments in the studies on the logic of collective action in corporate lobbying are also characterised by another aspect. Indeed, Olson's theory of collective action assumes a fortiori the feasibility and even the preferability of collective action. Scholars have started to (in the majority of cases, implicitly) challenge this assumption by introducing the division between collective and private goods into sectoral studies (e.g. in lobbying dynamics within determined manufacture industries, Godwin and Seldon, 2002) and then into broader approaches (e.g. Hansen et al, 2005; Lowery et al, 2008; Ozer and Lee, 2009; Godwin et al, 2008). In fact, ceteris paribus (i.e. regardless of the structure of the market) firms are incentivised by individual rents to act alone in the political arena. Unfortunately, public goods are not easily isolated from private ones, even in a rent seeking lobbying system such as the American one. The applicability of such an approach to the European reality, characterised by regulatory rent seeking lobbying (Coen, 2007; Coen, 2009; Fligstein and Stone Sweet, 2002), deserves further discussion.

\section{Resource Dependence Theory}

In the European Union, where the 'political currency' is represented neither by votes nor by the amount of money a firm can allocate to the campaign of a candidate, the issue of the size of a firm is more complicated. Nevertheless, there is a sort of 'belief' among European scholars that a firm's resources determine its political strategy. Even more implicit is the assumption that this is usually associated with the choice of a given political strategy: large firms prefer to lobby alone. This 'belief' is either implicit or explicit (e.g. Coen, 2007; Coen and Richardson, 2009; Eising , 2007; Bernhagen and Mitchell, 2009) in a great amount of works on European corporate lobbying without any attempt to provide any proper theoretical basis ${ }^{6}$. This stream of thought contradicts the Olsonian tradition by presenting opposite assumptions: individual action is here a fortiori conceived as preferable provided that a firm may afford it. Accordingly two hypotheses are inferred:

\section{H-e2: Ceteris paribus, large firms will be more likely to lobby directly}

H-c1: Ceteris paribus, large firms will be more likely to lobby both directly and collectively at industrial level

These hypotheses have been operationalised and tested by many American scholars and most extensively in the European realm by Bernhagen and Mitchell (2009) with positive results without, however, addressing due attention to the measurement of the dependent variable. Indeed, as will be illustrated below, scholars have hitherto fallen short in considering a firm's preference for the level of action and in constructing a multi-dimensional proxy of direct lobbying. In fact it is reasonable to assert that large firms will have the resources to employ a wider array of strategies 
than small ones. As a result, ceteris paribus large firms will be involved more in direct lobbying dynamics than small ones in absolute terms. Nevertheless, the aim of an effective analysis should be to reveal whether large firms prefer direct lobbying dynamics to collective ones thus controlling for the latter.

\section{Endowment-based Trade Models and Adjustment Costs}

The type and intensity of trade induced adjustment costs are derived from the characteristics of production factors. Assuming that the stakes of a firm depend on the intensity with which production factors are utilised along with the availability and costs of substitutes and the mobility of those factors (Alt et al, 1999), two main models are found in the literature (e.g. Alt and Gilligan, 1994; Gilligan, 1997): the Stolper-Samuelson (or Heckscher-Ohlin) theorem and the Ricardo-Viner theorem. The former refers to the scenario where factors (or assets) are mobile, namely the costs of reallocating them between industries are negligible. Accordingly, international trade bears the same effects on the rents of particular factors (i.e. wages or capital rents) regardless of where they are employed. The Stolper-Samuelson model envisages that an increase in trade raises the returns of the factor with which a country is abundantly endowed (Gilligan, 1997; Alt et al, 1999; Rogowski,1989). In this scenario, trade coalitions form along factoral or class lines (Gilligan, 1997; Alt et al, 1999). The Ricardo-Viner model assumes that factors are tied to the industry where they are employed (Alt et al, 1999) thus envisaging non trivial adjustment costs for import competing industries. Accordingly, trade policy coalitions form along industry lines.

Worthy of note is that collective action considerations, though being clearly more serious in a Stolper-Samuelson scenario since entire classes are supposed to coalesce, have always been neglected by these models (Gilligan, 1997). Indeed, the latter only aim to identify the conditions whereby interests of economic actors are similar. As a consequence, it is necessary to merge these models with the Olsonian argument: the former reveal how actors coalesce with each other and the latter foresees the collective action problems actors are likely to encounter. This is not completely unfamiliar to the literature, but it has hitherto been confined to the analyses of single case-studies (e.g. to US trade policy, Gilligan, 1997 or to the Norwegian subsidies to national industry, Alt et al, 1999). The hypothesis inferred is thus:

$\mathrm{H}$-e3: Ceteris paribus, firms acting in industries characterised by asset mobility will be more likely to lobby directly

After arguing for the necessity of unifying the assumptions of the Olsonian school and of the endogenous tariff literature, another development is of crucial importance in this field. It seems unreasonable that the role of factor specificity in determining coalitions among economic actors must be confined to trade policy lobbying. Other applications may be found: Alt et al (1999) apply this scheme to the demand for subsidies on the part of Norwegian industrial sectors in the 1970s. As underlined by Alt et al (1999 p. 114) 'though political science abounds with studies of lobbying, including lobbying by firms, we believe the application of trade theory and the measurements of firm characteristics we use represent a fruitful extension of a long empirical tradition'. In a similar vein, the next section will apply the concept of asset specificity to lobbying in the context of European decision-making as a whole and not exclusively to trade policy. The assumption is straightforward: the owners of the production factors who face potential losses due to an increase in competition will (at least partly) lobby instead of assuming adjustment costs, and the two models described above foresee how they will do it. Since the (formal) completion of the Single Market, trade between Member States has been regulated by a series of measures ranging from standard setting and procurement legislation, through Single Market directives to dispositions which indirectly affect competition, such as environmental policy. These regulations have the same characteristics as traditional trade policy as conceived by factor-endowments theories: they influence the way costs and benefits realign between different economic actors within and between 
two or more countries. In conclusion, this hypothesis represents a novel attempt to extend the analytical concept of asset specificity beyond the scope of trade policy lobbying.

\section{Industrial Organisation Theories}

Asset specificity has also been identified as a crucial factor in determining corporate political strategies by scholars drawing on industrial organisation theories (e.g. Ozer and Lee, 2009; Alt et al, 1999). Indeed, asset specificity determines long-term contracts along with firm organisation and therefore, the firm is incentivised to act in the political arena in order to secure its own environment (Ozer and Lee, 2009). The owner of specific assets is usually more involved in joint production and in the vertical structuring of its activities (Alt et al, 1999): vertical integration and long-term contracts make the firm more embedded in its environment. This scenario increases adjustment pressures and therefore, the firm facing potential losses increases expenditures on contractual activities that can reduce such losses. Among these activities Alt et al (1999) list lobbying. It is worth noting that whereas Alt et al (1999) apply this logic to test whether asset specificity leads to an increase in lobbying activities regardless of the level of action, Ozer and Lee (2009) employ asset specificity as a moderator of the negative relation between industrial concentration and individual action. In the latter case, firms with specific factors lobby directly. The following section embraces both these assumptions:

$\mathrm{H}$-e3(bis): Ceteris paribus, firms acting in industries characterised by asset specificity will be more likely to lobby directly

H-c2: Ceteris paribus, firms acting in industries characterised by asset specificity will be more likely to lobby both directly and collectively at industrial level

Furthermore, another scenario where the firm is so embedded in its environment that it is incentivised to act alone is identified: when the firm is highly involved in international joint production with a series of arrangements with foreign firms. Then:

\section{H-e4: Ceteris paribus, firms involved in high foreign investments will be more likely to lobby directly}

\section{Regulatory Exposure}

As already illustrated, several authors (e.g. Ozer and Lee, 2009; Hansen et al, 2005; Godwin et al, 2008) emphasise the importance of the division between public and private goods. Private rents impart benefits to a single actor exclusive of others, whereas collective rents are non-excludable, namely benefits are evenly allocated amongst a group of actors (Hansen et al, 2005). In the American context, indeed, firms are moved predominantly by rent seeking (Ozer and Lee, 2009). Individual government contracts represent an incentive for the firm to act alone in the political arena. Conversely, collective rents incentivise firms to coalesce and act as a united actor. Accordingly, the hypothesis is:

$\mathrm{H}$-e5: Ceteris paribus, firms highly involved in the delivering of private rents will be more likely to lobby directly

Apart from the already mentioned considerations on the analytical difficulties in clearly distinguishing private goods from public ones, the applicability of this approach to the European context involves immense difficulties. Bernhagen and Mitchell (2009) operationalise the European involvement in a sector as a relevant factor. The logic is straightforward: the more EU legislation is active in a sector, the more the firms in that sector will lobby. One caveat must be considered though: the two authors do not consider the level of action relevant, in other words EU involvement determines the action of the firm, being individual or collective lobbying. Whether the division between collective and individual goods can be applied to the European regulatory rent seeking 
system of lobbying is the focus of the following section, which illustrates the analytical problems in the operationalisation of this hypothesis. Bernhagen and Mitchell's (2009) conception has been maintained:

H-c4: Ceteris paribus, firms acting in industries highly affected by EU regulation will be more likely to lobby both directly and collectively at industrial level

\section{Data and Measurement}

This section presents the data set utilised and how the hypotheses shown above are translated into relationships among variables. After some initial considerations on the database used and the modifications made to it, the identification and the operationalisation of the variables follow.

The Data Set

This study builds on the valuable database provided by Bernhagen and Mitchell $(2009)^{7}$ for a specific reason. At the time of writing this data set represented the first and only attempt to analyse the economic determinants of European corporate lobbying. Accordingly, it is the best context to employ the analytical devices outlined above. By utilising the same data, this clearly demonstrates not only the applicability of a multidimensional operationalisation of corporate lobbying to the European domain, but also the necessity.

The data set is drawn from Forbes Global $2000^{8}$ and comprises the 2009 largest firms in 2005 representing 50 countries and 27 industrial sectors. The database was modified in many regards to fit this work: some variables were ignored, some added and others were operationalised differently. For convenience, Bernhagen and Mitchell's (2009) variables which are to be employed in the analysis below, along with their proxies and sources, are shown in Table $1^{9}$. The data set was also limited to European firms. As a result, the reduced data set has 479 European firms, from 12 countries and involving 27 industries. Reducing the observations creates problems. Nevertheless, three considerations drove this decision. First, whilst there are no widely adopted guidelines on the minimum number of observations a quantitative analysis must rely on, 479 observations represent a significant number. Second, the distribution of the variables does not change drastically due to such a modification: all the 27 economic sectors are still present, for instance. Indeed, also Bernhagen and Mitchell (2009) themselves explore this option without skewing results. Third, practical considerations on the operationalisation of variables were taken into account: consistency in the measurement of indicators is always desirable for reliable research.

\section{(Table 1)}

\section{Adding Variables}

This section illustrates and operationalises the variables to be integrated into Bernhagen and Mitchell's (2009) database. Indeed, the novel theoretical approaches applied and the relative hypotheses inferred necessitate additional variables. Since for the Olsonian argument and the resource dependence theory the relevant variables (respectively, industry concentration and firm size) were already operationalised and measured (see Table 1), this section deals with the remaining models. It is worth noting that the operationalisation of the variables hereafter focuses on the industry level and not on the individual firm level for two reasons. First of all, the concepts introduced make sense exclusively when employed at that level: in the economic literature asset specificity is always associated with industries and not individual firms. Secondly and accordingly, data are available only at industry level. The same rationale lies behind the operationalisation of several variables in the study by Bernhagen and Mitchell (2009).

\section{Factor-endowments Trade Theories and Industrial Organisation Theories}

Despite starting from different perspectives, both factor-endowments trade models and industrial organisation theories indicate asset specificity as a determinant of corporate political action. 
Consensus reigns in the literature (e.g. Alt et al, 1999; Ozer and Lee, 2009) over the operationalisation of the abstract concept of 'asset specificity' into two proxies: R\&D expenditures and job mobility. Indeed, the former represent capital specificity whereas the latter labour force specificity. Furthermore, R\&D expenditures also represent an indicator of the stake a firm has in its environment according to the industrial organisation approach (Ozer and Lee, 2009). Accordingly, asset specificity regarding capital was operationalised into the ratio of $R \& D$ expenditures over value added. Data were drawn from Eurostat for each industry in each of the countries contained in the dataset and assigned to firms accordingly: Business Enterprise R\&D Expenditure (BERD) has been divided for Gross Value Added (GVA) at basic prices. The ratios for eight years, namely from 1999 to 2006, were calculated and then averaged over the period. The correspondence between the different classification methods constituted the most challenging problem addressed along the entire process of data gathering. Indeed, for what regards this variable, data on BERD and GVA were classified according to the NACE Revision 1 system. This was rather similar to that utilised in the database, nevertheless, great effort was made to ensure the right correspondence between differently classified economic activities for each observation. For instance, in this particular case 'insurance' in Bernhagen and Mitchell's (2009) database was associated with a generic 'financial intermediation'.

The concept of asset specificity on the side the labour force is more difficult to operationalise. Alt et al (1999) identify job mobility with the assumption that high variations in the labour force of a sector reveal asset mobility. Nevertheless, job mobility is a multifaceted phenomenon, involving movements between employers (job-to-job mobility); between occupations and steps on the career ladder (occupational mobility); between different types of contracts; and in and out of employment (employment mobility) (Danish Technological Institute, 2008). Factor-endowments models indicate frictions in the reallocation of the labour force between different sectors as a relevant indicator for adjustment costs. Accordingly, this refers to the level of closeness characterising the labour market in a given sector vis-à-vis those in the other sectors. In empirical research analytical considerations must be balanced with operational ones. Indeed, perfect measurements for this variable would be the specific flows of the labour force across industries, thus focusing only on job-to-job mobility, and job tenure within sectors, which 'is measured by the length of time workers have been in their current or main job or with their current employer' (OECD, 2007). Since no data divided per economic sector are available for this proxy, job mobility was measured through the Industry Labour Input Index available in the Eurostat database (again, for each industry in the countries comprised in the dataset). This index indicates the percentage of the change in the gross number of employees per industry compared to the corresponding period of the previous year. Data were transposed into absolute terms, as this study is interested only in the intensity of the variation and not in its sign. Again, this was measured for a period of eight years (from 1999 to 2006) and averaged for this period. Problems related to classification methods arouse also in this case, as this index was categorised according to the NACE Revision 2. For instance 'aerospace' was in this case associated with 'manufacture of other transport equipment'.

Along with asset specificity, industrial organisation theories identify another relevant determinant of a firm's political action. Indeed, the net of foreign investments and contracts with foreign firms in which a firm is embedded incentivises the firm to lobby directly in order to secure the environment where it acts. The level of assets an individual firm has abroad was operationalised into the level of FDI stocks in a given industry. Accordingly, data on FDI stocks (comprising equity capital and reinvested earnings plus other FDI capital) for each European MS vis-à-vis the others and for each sector were drawn from Eurostat. Consistently with other data in the dataset, FDI stocks were measured for the year 2006. Difficulties in comparing different databases emerged since data on FDI stocks referred to the NACE Revision 1. Nevertheless, a more accurate correspondence was possible in this case since the level of aggregation of available data was lower. As a result, in this case it was possible to associate 'aerospace' with 'manufacturing of aircraft and spacecraft'. 


\section{Regulatory Exposure}

As shown above, several authors close to the American tradition (e.g. Ozer and Lee, 2009; Hansen et al, 2005; Godwin et al, 2008) emphasise the division between private and public rents delivered by the political system as a determinant of corporate political action. In a rent seeking system, such as American lobbying, the operationalisation of this concept is troublesome, but feasible. Conversely in a regulatory rent seeking system, such as European lobbying, this process is not straightforward. Furthermore, the literature is not of help in this case since the concept of private and public rents has hitherto not been applied to the European context. Nevertheless, this part operationalises this determinant building on the following assumptions. Bernhagen and Mitchell's (2009) variable labelled 'EU involvement' is associated with the concept of private regulatory rent. The concept of regulatory rent or regulation as a good has already been employed by Hansen et al (2005). The rationale is that the times a firm has been mentioned in European court cases and in European regulatory proceedings is utilised as a proxy of European Union involvement in the environment of an individual firm. Accordingly, the more a firm is involved in the European system as a single actor, the more it can benefit or lose as a single actor being thus incentivised to act individually.

Conversely, the more the EU is involved in a sector, the more the firms in that sector can benefit or lose as a collective actor thus being incentivised to act collectively. This is the logic behind a public regulatory rent. As a consequence, a measure of the European involvement in a sector is needed: for each sector in the database an estimation of the staff working on issues closely related to it was drawn from the organisation chart of EU Commission staff ${ }^{10}$. Accordingly, more accurate measures of the involvement of the EU in a specific sectors were taken rather than considering as a proxy the entire staff of the DG officially in charge (as proposed by Mahoney, 2004). For instance, the relevant DG for the sector 'aerospace' is the DG ENTR and therefore, according to Mahoney's (2004) measurement the value of EU involvement would be 770 , namely the number of employees of such a DG. Nevertheless, only a portion of those 770 officials deal directly with the aerospace sector: only the ones in the DG ENTR D.4 and in the DG ENTR H for a total of 136 employees. Furthermore, taking as an example 'chemicals sector' the staff dealing with these issues is employed both in the DG ENTR, namely DG ENTR G, in the DG ENV, namely DG ENV D , and in the DG RESEARCH, namely DG RESEARCH G.3. This results in a more detailed measurement of the proxy of public regulatory rent results. Other considerations on the suitability of this concept for the European domain are left to the results of the empirical analysis. Table 2 illustrates the statistical characteristics of the variables mentioned above.

\section{(Table 2)}

\section{Analysis}

After having operationalised and measured the relevant determinants of corporate political action this section proposes two operational definitions of direct lobbying each of which with slightly different characters. Such a multidimensional operationalisation of the dependent variable aims to overcome the issues which characterise dichotomous and uni-dimensional operational definitions.

\section{Direct Lobbying: a Multi-strategy Proxy}

Hansen et al (2005) identify two different strategies according to which firms lobby directly in the US system: lobbying for an individual candidate running for elections and soft-money contributions to political parties. Furthermore, Alt et al (1999) in their analysis of the 'Norwegian case' recognise the necessity of differentiating the frequency at which firms contact political actors. Under this light, this section operationalises the dependent variable 'direct lobbying' as an ordinal variable using the dichotomous ones identified by Bernhagen and Mitchell (2009). An operational condition must be met in order to construct such a variable: the values of the ordered variable must be mutually exclusive and collectively exhaustive (Borooah, 2002). Table 3 illustrates the procedure whereby this novel variable, labelled 'ordered direct lobbying', was from Bernhagen and Mitchell's (2009) 
data. The variable 'ordered direct lobbying' assumes six values: from value 1 (i.e. 'no direct lobbying') to value 6 (i.e. 'very high direct lobbying'). For instance, if a firm is not accredited to the $E P$, it does not have a full-time European affairs representative and it has not established a company office in Brussels, the firm at stake is given the value 1 associated with 'no direct lobbying'. Needless to say, the weight assigned to 'Brussels office' in the construction of this new variable is superior to the one assigned to 'EP lobbyist', for instance. Table 4 illustrates the characteristic of the dependent variable.

(Table 3)

(Table 4)

Since the dependent variable represents the coding of qualitative outcomes and it assumes more than two values with an inherent order two regression methods are appropriate: the ordered logit and the ordered probit (Borooah, 2002). The difference between these two methods is rather technical and no guidelines driving the choice on theoretical grounds are present (Greene, 2000): in a logit distribution standard errors are logistically distributed whereas in a probit one they are normally distributed (Vasisht, 2007). An ordered logit method was chosen in order to be in line with Bernhagen and Mitchell's (2009) analysis.

\section{(Table 5)}

As illustrated in Table 5, the hypothesis relating size with direct lobbying is verified since the estimated coefficient is statistically significant and of the right sign. Accordingly, taking two firms equal in all characteristics, the larger one is more likely to be involved in direct lobbying than the smaller one. Nonetheless, the strength of the variable size in this model is rather low. The reason being that the multi-strategy operationalisation of the variable 'direct lobbying' supplies a comprehensive overview of the phenomenon to be analysed including also strategies not directly linked to the resource availability of a firm. If direct lobbying is exclusively associated with the establishment of a company office in Brussels or the appointment of a European affairs representative, it can easily be predicted that firm size will matter. In fact, these two represent rather costly strategies. Accordingly, a researcher must rely on the complete spectrum of strategies a firm may employ and assign them the due weight. As a conclusion, whilst size retains its status of determinant of direct lobbying, its strength is significantly scaled down. Resource dependence theory atones for its shaky theoretical grounds in the empirical realm thanks to an operational definition of direct lobbying comprising the different strategies a firm can employ. The hypothesis which puts into relation the delivery of private rents with direct lobbying is sustained. The estimated coefficient of this explanatory variable is of the expected sign.

\section{Direct Lobbying: a Multi-venue Proxy}

Although the model above furnishes a comprehensive analysis of the phenomenon of direct lobbying by considering the various strategies employed by firms, direct lobbying, in fact, should be analysed in relative terms vis-à-vis other lobbying venues. Accordingly, the factors determining direct lobbying as a preferable strategy must be isolated. Ozer and Lee (2009) in their analysis of the lobbying dynamics characterising the American manufacturing industry employ as a dependent variable corporate 'relative' direct lobbying. It should be noted that American lobbying is a more 'observable and measurable' reality than the European one in many regards: for instance, the highly regulated practice of Political Action Committee (PAC) contributions facilitates operationalisation. With these analytical advantages, Ozer and Lee (2009) compute the ratio between PAC contributions via industrial associations and PAC contributions devolved as individual firms as the dependent variable. European reality does not facilitate the operationalisation of corporate relative direct lobbying: in the European lobbying context proxies of the actual action of interest groups, such as the PAC contributions, are very difficult to extrapolate. 
As a result, the analysis will focus on the number of industry associations. The next part will operationalise direct European lobbying as a preference over collective action through European industry associations.

Bernhagen and Mitchell's (2009) variable 'industry associations', measuring the number of trade, industry or employers' Euro groups per sector, was utilised to operationalise the dependent variable analysed in this section. The number of company representation offices in Brussels representing firms in a sector was divided for the number of industry associations in that sector: a multi-venue proxy of corporate lobbying at industry level results. This dependent variable was labelled 'direct lobbying over European'. This shifts the focus of analysis to the industry level. Accordingly, all the other variables were adjusted for that level: the average size of firms in a sector was computed, for instance. Table 6 represents the results of the calculations for the dependent variable 'direct lobbying over European'.

\section{(Table 6)}

Four variables are found to be statistically significant: industry concentration, job mobility, EU involvement (public rents) and EU involvement (private rents). Industry concentration is negatively correlated with direct lobbying: this is in line with the prediction of the Olsonian argument. Indeed, thanks to the multi-venue operationalisation of direct lobbying employed in this study it is demonstrated that the more an industry is concentrated the more the firms producing therein prefer collective action rather than direct lobbying. From the regression model it can be inferred that job mobility is positively associated with direct lobbying. Industrial organisation theories state that asset specificity is associated with a higher involvement of firms in the European arena both directly and at industry level. This hypothesis is falsified because asset specificity influences the involvement in direct lobbying and industry level lobbying in different degrees. Conversely, this finding is in line with the argument deriving from the fusion of the assumptions of the factor endowments trade theories and of the Olsonian tradition: in an asset mobility scenario coalitions should form along factoral/class lines, but, as the latter are characterised by huge collective action problems, the firm lobbies alone. This is another confirmation of the empirical support the Olsonian argument finds if a multi-venue proxy of corporate lobbying is employed.

From the regression model it can be induced that private regulatory rents supplied by the EU are negatively associated with direct lobbying. Indeed, given the operationalisation of direct lobbying as a ratio over industry lobbying at European level, EU private rents are associated with a high involvement in industry lobbying. Furthermore, despite being statistically significant, the strength of the effect of EU public regulatory rents is negligible. This casts doubts on the applicability of the division between public and private regulatory rents to the European context. Nevertheless, the fact that in this model such a relationship is very weak is in line with the general assumption that a firm embarks more heavily in lobbying practices at European level when its environment is heavily affected by EU legislation, regardless of the lobbying venue. Accordingly, the division between public and private goods must be set aside (at least until a more effective operationalisation is excogitated) though the general concept of EU involvement as a determinant of a firm's action at European level (being direct or collective lobbying) is maintained.

The operationalisation of direct lobbying as a ratio over industry lobbying at European level emphasise some aspects. First of all, firm size is not statistically significant. This variable, after being scaled down by the analysis of the different lobbying strategies, is completely nullified by taking into consideration the other European venue a firm may exploit to lobby. Accordingly, both the hypotheses associated with resource dependence theory do not find any empirical support in this study. The disproportionate role assigned to the size of a firm as a determinant of corporate lobbying (and even direct corporate lobbying) by many scholars can be attributed to the investigative weakness uncovered by this analysis: a uni-dimensional operationalisation of direct 
lobbying. Furthermore, the operationalisation of the division between public and private regulatory rents, although being theoretically appealing, proves to be analytically unfeasible in the European context. Indeed, the markedly regulatory character of the role of the EU in firms' environment represents a strong obstacle. Nevertheless, with its innovative theoretical considerations this study can pave the way for future research: more work should be devoted to the operationalisation of this concept. Unsurprisingly, the level of EU involvement in a sector incentivises firms to act at European level exploiting both the lobbying venues available.

\section{Conclusion}

The contribution of this study is twofold. On the theoretical side, the main economic theories on corporate lobbying are transposed from the American lobbying system to the European one: the Olsonian argument and industrial organisation theories are brought in. Furthermore, the scope of analysis of trade policy lobbying theories is widened arguing that they can be appropriate also for the interest representation system as a whole and not only circumscribed to trade policy.

On the analytical side, two main novelties are introduced in order to analyse European corporate lobbying in its multifaceted character: a multi-strategy and a multi-venue perspective. The several strategies characterising direct lobbying are considered and a specific weight is assigned to each of them. Moreover, the various venues a firm can exploit to lobby the EU are taken into consideration. As a consequence, a theoretically and empirically balanced analysis of the economic structure of incentives determining firms' political action is presented.

As a conclusion, the structure of economic incentives driving firms' political action can be illustrated as follows. For firms, if the various lobbying strategies characterising direct lobbying and its intensity are taken into consideration, resources do play a decisive role, though perhaps less decisive than that suggested in the literature. The role of resources is cancelled out if the different venues via which a firm can lobby the EU are considered. Accordingly, resources are relevant with respect to direct lobbying in absolute terms, but if direct lobbying is analysed as a preference over the other European lobbying venues they are not. Concerning factors at industry level, asset specificity/mobility determines a firm's preference to lobby directly vis-à-vis other venues: the assumptions of the factor-endowments trade theories (with the contribution of the Olsonian argument) are demonstrated. Moreover, if direct lobbying is operationalised as a preference over a collective technique the Olsonian argument finds empirical support.

\section{References}

Alt, J.E. and Gilligan, M. (1994) The political economy of trading states. Journal of Political Philosophy 2 (2):165-92.

Alt, J.E., Carlsen, F., Heum, P. and Johansen, K. (1999) Asset specificity and the political behaviour of firms: Lobbying for subsidies in Norway. International Organization (53)1: 99-116.

Baumgartner, F. R. and Leech, B.L. (1998) Basic Interests: The Importance of Groups in Politics and Political Science. Princeton: Princeton University Press.

Baumgartner, F.R. and Jones, B. D. (1993) Agendas and instability in American politics. Chicago: University of Chicago Press.

Berkhout, J. and Lowery, D. (2010) The changing demography of the EU interest system since 1990. European Union Politics 11(3): 447-461.

Bernhagen, P. and Mitchell, N. (2009) The determinants of direct corporate lobbying in the European Union. European Union Politics 10(2): 155-176. 
Bhagwati, J. N. (1982) Adjustment processes and policies: Theoretical issues. In: Bhagwati, J. N. (ed.), Import Competition and Response. Chicago: University of Chicago Press.

Borooah, V. (2004) Logit and Probit: Ordered and Multinomial Models. London: SAGE.

Broscheid, A. and Coen, D. (2003) Insider and outsider lobbying of the European Commission, European Union Politics 4(2): 165-189.

Coen, D. (1998) The European business interest and the nation state: Large-firm lobbying in the European Union and Member States. Journal of Public Policy 18(1): 75-100.

Coen, D. (2007) Lobbying in the European Union. PE 393.266.

Coen, D.(2009) Business lobbying in the European Union. In: Coen, D. and Richardson, J. (ed.), Lobbying the European Union: Institutions, Actors and Issues. Oxford: Oxford University Press.

Coen, D. and Richardson, J. (2009) Learning to lobby the European Union: 20 years of change. In: Coen, D. and Richardson, J. (ed.), Lobbying the European Union: Institutions, Actors and Issues. Oxford: Oxford University Press.

Danish Technological Institute (2008) Job Mobility in the European Union: Optimising its Social and Economic Benefits. Policy and Business Analysis.

Eising, R. (2007) The access of business interests to EU political institutions: Towards elite pluralism?. Journal of European Public Policy 14(3): 346-365.

Esty, D. and Caves, R.E. (1983) Market structure and political influence: New data on political expenditures, activity and success. Economic Inquiry 21(1): 24-38.

Fligstein, N. and Stone-Sweet, A. (2002) Constructing polities and markets: An institutionalist account of European integration. American Journal of Sociology 107(5): 1206-43.

Furusawa, T. and Lai, E. (1999) Adjustment costs and gradual trade liberalization. Journal of International Economics 49: 333-361.

Gilligan, M. (1997) Lobbying as a private good with intra-industry trade. International Studies Quarterly 41: 455-474.

Godwin, K. R. and. Seldon, B. J (2002) What corporations really want from government: The public provision of private goods. In: Cigler, A. and Loomis, B. (eds), Interest Group Politics. Washington DC: CQ Press.

Godwin, K.R., Lopez, E. J. and Seldon, B.J. (2008) Allocating lobbying resources between collective and private rents. Political Research Quarterly 61: 345.

Gray, V. and Lowery, D. (1996) The Population Ecology of Interest Representation. Ann Arbor: University of Michigan Press.

Greene, W. (2000) Econometric Analysis. Prentice Hall: Pearson. 
Hansen, W. L., Mitchell, N. J. and Drope, J. M. (2005) The logic of private and collective action. American Journal of Political Science 49(1): 150-167.

Kassim, H. (2005) The Europeanization of Member State institutions. In: Bulmer, S. and Lequesne, C. (ed.), The Member States of the European Union. Oxford: Oxford University Press.

Lowery, D. and Gray, V. (2004) A neopluralist perspective on research on organized interests. Political Research Quarterly 57(1): 163-75.

Lowery, D., Poppelaars, C. and Berkhout, J. (2008) The European Union interest system in comparative perspective: A bridge too far?. West European Politics 31(6): 1231-1252.

Mahoney, C. (2004) The power of institutions state and interest group activity in the European Union. European Union Politics 5(4): 441-466.

Munger, M. C. (1988) On the political participation of the firm in the electoral process: An update. Public Choice, 56: 295-98.

OECD (2007) The OECD Glossary of Statistical Terms. Organization for Economic Co-operation and Development.

Olson, M. (1965) The Logic of Collective Action: Public Goods and the Theory of Groups. Cambridge: Harvard University Press.

Ozer, M. and Lee, S. (2009) When do firms prefer individual action to collective action in the pursuit of corporate political strategy? A new perspective on industry concentration. Business and Politics 11(1): 1-21.

Rogowski, R. L. (1989) Commerce and Coalitions. Princeton: Princeton University Press.

Vasisht, A.K. (2007) Logit and Probit Analysis. New Delhi: Technical report: I.A.S.R.I. 
Tables

Table 1: Bernhagen and Mitchell (2009) Variables

\begin{tabular}{|c|c|c|}
\hline & Proxies & Sources \\
\hline \multirow[t]{3}{*}{ Direct Lobbying } & Brussels office & \multirow{3}{*}{$\begin{array}{l}\text { European Public Affairs Directory } \\
2006\end{array}$} \\
\hline & European affairs representative & \\
\hline & EP lobbyist & \\
\hline \multirow[t]{2}{*}{ Size } & Sales & \multirow[t]{2}{*}{ Forbes Global 2000 (December 2005) } \\
\hline & Profits & \\
\hline $\begin{array}{l}\text { Regulatory } \\
\text { exposure }\end{array}$ & $\begin{array}{l}\text { Appearances in the EU court cases } \\
\text { and in the regulatory proceedings of } \\
\text { the Commission }\end{array}$ & $\begin{array}{l}\text { CONECCS database, available at } \\
\text { http://ec.europa.eu/civil_society/conec } \\
\text { cs/index.html [Accessed 19 March } \\
\text { 2006]; EUR-Lex case law; available } \\
\text { at: } \\
\text { lex.europa.eu/en/index.htm [Accessed } \\
6 \text { February 2006] }\end{array}$ \\
\hline & Four-firm ratio & Forbes Global 2000 (December 2005) \\
\hline \multirow{2}{*}{$\begin{array}{l}\text { Control } \\
\text { variables } \\
\text { (sectoral level) }\end{array}$} & Associations per industry & \multirow{2}{*}{$\begin{array}{l}\text { European Public Affairs Directory } \\
2006\end{array}$} \\
\hline & National associations & \\
\hline
\end{tabular}

Source: Online Appendix 2 of Bernhagen and Mitchell (2009) available at http://www.abdn.ac.uk/ pol209/data.htm [Accessed 10 August 2011] and Bernhagen and Mitchell (2009). Author's own compilation.

Table 2: Added Variables

\begin{tabular}{|l|l|l|l|l|}
\hline & Mean & $\begin{array}{l}\text { Standard } \\
\text { deviation }\end{array}$ & Variance & $\begin{array}{l}\text { Coefficient of } \\
\text { variation }\end{array}$ \\
\hline FDI & 83.43435 & 195.2873 & 38137.14 & 2.34061 \\
\hline R\&D intensity & $5.12 \mathrm{e}+09$ & $1.02 \mathrm{e}+11$ & $1.05 \mathrm{e}+22$ & 20.00494 \\
\hline Job mobility & 2.317333 & 2.381583 & 5.67194 & 1.027726 \\
\hline IIT involvement & 79.36732 & 11.13709 & 124.0349 & .1403234 \\
\hline $\begin{array}{l}\text { EU in } \\
\text { (public rents) }\end{array}$ & 328.2359 & 260.3885 & 67802.17 & .7932968 \\
\hline
\end{tabular}

Source: Author's own calculations and compilation. 
Table 3: 'Ordered Direct Lobbying' Variable: Procedure

\begin{tabular}{|c|c|c|c|c|}
\hline \multicolumn{3}{|c|}{ Bernhagen and Mitchell's (2009) variables } & \\
\hline $\begin{array}{l}\text { European affairs } \\
\text { representative }\end{array}$ & EP lobbyist & $\begin{array}{l}\text { Brussel } \\
s \text { office }\end{array}$ & Lobbying' varia & able \\
\hline 0 & 0 & 0 & $\begin{array}{l}\begin{array}{l}\text { No direct } \\
\text { lobbying }\end{array} \\
\end{array}$ & 1 \\
\hline 0 & 1 & 0 & $\begin{array}{l}\text { Very low direct } \\
\text { lobbying }\end{array}$ & 2 \\
\hline 1 & 0 & 0 & $\begin{array}{l}\text { Low direct } \\
\text { lobbying }\end{array}$ & 3 \\
\hline 1 & 1 & 0 & $\begin{array}{l}\text { Medium direct } \\
\text { lobbying }\end{array}$ & 4 \\
\hline 1 & 0 & 1 & $\begin{array}{l}\text { High direct } \\
\text { lobbying }\end{array}$ & 5 \\
\hline 1 & 1 & 1 & $\begin{array}{l}\text { Very high } \\
\text { direct lobbying }\end{array}$ & 6 \\
\hline
\end{tabular}

Source: Author's calculations and compilation.

Table 4: ‘Ordered Direct Lobbying' Variable: Characteristics

\begin{tabular}{|l|l|l|l|l|l|l|}
\hline & Mean & Std. Dev. & Min & Max & Variance & Skewness \\
\hline 'Ordered Direct Lobbying' & 1.99789 & 1.767093 & 1 & 6 & 3.122617 & 1.545064 \\
\hline
\end{tabular}

Source: Author's calculations and compilation.

Table 5: 'Ordered Direct Lobbying'

\begin{tabular}{|l|l|l|l|l|l|l|}
\hline 'Ordered Direct Lobbying' & Coef. & Std. Err. & $\mathbf{Z}$ & $\mathbf{P > \mathbf { Z }}$ & [95\% Conf.Interval] \\
\hline Size & .0524839 & .0129751 & 4.04 & 0.000 & .027053 & .0779147 \\
\hline Industry Concentration & 2.845379 & 2.10405 & 1.35 & 0.176 & -1.278484 & 6.969242 \\
\hline R\&D intensity & $7.51 \mathrm{e}-09$ & $1.99 \mathrm{e}-07$ & 0.04 & 0.970 & $-3.82 \mathrm{e}-07$ & $3.97 \mathrm{e}-07$ \\
\hline Job mobility & .1943854 & .1401619 & 1.39 & 0.165 & -.0803268 & .4690977 \\
\hline FDI & .001344 & .0007603 & 1.77 & 0.077 & -.0001461 & .0028341 \\
\hline EU involvement (public rents) & 18.14091 & 4.004934 & 4.53 & 0.000 & 10.29138 & 25.99044 \\
\hline EU involvement (public rents) & -.0000291 & .0010052 & -0.03 & 0.977 & -.0019993 & .0019412 \\
\hline
\end{tabular}


Table 6: 'Direct Lobbying over European'

\begin{tabular}{|l|l|l|l|l|l|l|}
\hline $\begin{array}{l}\text { 'Direct Lobbying over } \\
\text { European' }\end{array}$ & Coef. & Std. Err. & $\mathbf{t}$ & P>t & \multicolumn{2}{l|}{ [95\% Conf.Interval] } \\
\hline Size & .0017725 & .0022678 & 0.78 & 0.436 & -.0027085 & .0062535 \\
\hline Industry Concentration & -1.363538 & .3971036 & -3.43 & 0.001 & -2.148178 & -.5788993 \\
\hline R\&D intensity & .0022438 & .0032137 & 0.70 & 0.486 & -.0041063 & .0085938 \\
\hline Job mobility & .1313687 & .0209903 & 6.26 & 0.000 & .0898939 & .1728436 \\
\hline FDI & -.0000694 & .0001588 & -0.44 & 0.663 & -.0003832 & .0002444 \\
\hline EU involvement (public rents) & .0006119 & .0001837 & 3.33 & 0.001 & .000249 & .0009748 \\
\hline EU involvement (private rents) & -3.827108 & .8548873 & -4.48 & 0.000 & -5.516285 & -2.137932 \\
\hline
\end{tabular}




\section{Notes}

1 The word 'strategy' refers to the manner whereby an actor deploys its resources in a practical way within a given venue. For instance, within the venue 'European direct lobbying' a firm can appoint a European public affairs representative, establish a company representation office etc.

2 The word 'venue' is preferred to the word 'level' because the former bears a broader meaning not restricted to the categorisation sub-national, national, supra-national (in this case, European).

${ }^{3}$ The principal hypotheses, namely the ones from which explanatory variables will be derived, are labelled as follows: $H$ e1, $H-e 2, H-e 3$ etc.

${ }^{4}$ The hypotheses from which control variables will be derived are labelled as follows: $H-c 1, H-c 2, H-c 3$ etc.

${ }^{5}$ This term was coined in a study on US lobbying in nuclear policy carried out by Baumgartner and Jones (1993). It indicates the framing of an issue in order to adapt it to the most receptive governance level. In European lobbying studies this term has come predominantly to the fore since the mid-1990s (e.g. Baumgartner, 2007; Broscheid and Coen, 2007) and it has been associated with the shift in the access points utilised by interest groups.

${ }^{6}$ This accusation refers to 'the simple resource-based perspective that ignores critical resource dependencies [and] that it assumes that interest groups are always prepared to modify and Europeanize their strategies as soon as their material self-interests would require or their resources would enable them to do so' (Beyers and Kerremans, 2007 p.464 emphasis added).

7 Available at http://www.abdn.ac.uk/ pol209/data.htm [Accessed 10 August 2011]. Information on each variable is available in the Online Appendix 2 http://www.abdn.ac.uk/ pol209/data.htm [Accessed 10 August 2011]. I am particularly grateful to Prof. Bernhagen, who kindly allowed me to utilise such a data set.

${ }^{8}$ http://www.forbes.com/2005/03/30/05f2000land.html [Accessed 22 August 2011].

${ }^{9}$ For details on the measurement of these variables consult directly Bernhagen and Mitchell (2009).

${ }^{10}$ Available at http://ec.europa.eu/staffdir/plsql/gsys_page.display_index?pLang=EN [Accessed 15 September 2011]. 